\title{
Chiral Ureas with Two Electronegative Substituents at 1-N: An Unusual Case of Coexisting Pyramidal and Almost Planar 1-N Atoms in the Same Crystal
}

\author{
OLEG V. SHISHKIN, ${ }^{1}$ VASILIY G. SHTAMBURG, ${ }^{2}$ ROMAN I. ZUBATYUK, ${ }^{1}$ DMITRIY A. OLEFIR, ${ }^{2}$ \\ ALEXANDER V. TSYGANKOV, ${ }^{2}$ ALEXANDER V. PROSYANIK, ${ }^{2}$ ALEXANDER V. MAZEPA, ${ }^{3}$ AND REMIR G. KOSTYANOVSKY ${ }^{1,4 *}$ \\ ${ }^{1}$ STC "Institute for Single Crystals", National Academy of Sciences of Ukraine, Kharkov, Ukraine \\ "Ukrainian State Chemical Technological University, Dnepropetrovsk, Ukraine \\ ${ }^{3}$ A.V. Bogatsky Physiko-Chemical Institute, National Academy of Sciences of Ukraine, Odessa, Ukraine \\ ${ }^{4}$ Laboratory of Stereochemistry, N.N. Semenov Institute of Chemical Physics, Russian Academy of Sciences, Moscow, Russian Federation
}

Dedicated to the $160^{\text {th }}$ Anniversary of Louis Pasteur's Discovery

\begin{abstract}
XRD studies of structure of $N$-acetoxy- $N$-methoxyurea and $N, N$-bis (methoxycarbonyl)- $N$-methoxyimide have revealed that in $N$-methoxy- $N$-X-ureas $(\mathrm{X}=$ $\mathrm{OAc}, \mathrm{Cl}, \mathrm{OMe}, \mathrm{N}^{+} \mathrm{C}_{5} \mathrm{H}_{5}$ ) the additional shortening of $\mathrm{N}-\mathrm{OMe}$ bond took place, which arising from an $\mathrm{n}_{\mathrm{O}(\mathrm{Me})^{-}-\sigma^{*} \mathrm{~N}-\mathrm{X}}$ anomeric orbital interaction. XRD studies of $N$-chloro- $N$ ethoxyurea crystal have revealed the presence of two kinds of anomeric nitrogen configuration in the $\mathrm{O}-\mathrm{N}-\mathrm{Cl}$ group in the form of a pyramidal configuration and a planar configuration for same 1-N nitrogen atom. XRD studies of $N$-4-chlorobenzoyloxy$\mathrm{N}$-ethoxyurea have revealed that the degree of pyramidality of the $1-\mathrm{N}$ nitrogen in $\mathrm{N}$ aroyloxy- $N$-alkoxyureas is tuned by orientation of benzoyl group with respect to the $\mathrm{N}-\mathrm{O}$ bond, which in turn depends of size of $\mathrm{N}$-alkoxy group. Chirality 21:642-647, 2009. 2008 Wiley-Liss, Inc.
\end{abstract}

KEY WORDS: $N$-acyloxy- $N$-alkoxyureas; $N$-chloro- $N$-alkoxyureas; nitrogen configuration; bond length

\section{INTRODUCTION}

The bonding of the nitrogen atom to two electronegative substituents possessing lone electron pairs (e.g., alkoxy groups in $N, N$-dialkoxy- $N$-tert-alkylamines ${ }^{1}$ ) stabilizes pyramidality of the nitrogen atom and increases its inversion barrier. ${ }^{1-4}$ The pyramidality of nitrogen in the $\mathrm{O}-\mathrm{N}-\mathrm{X}$ geminal system $\left(\mathrm{X}=\mathrm{OC}(\mathrm{O}) \mathrm{R}, \mathrm{OAlk}, \mathrm{N}^{+} \mathrm{C}_{5} \mathrm{H}_{5}, \mathrm{Cl}\right)$ in $\mathrm{N}$ acyloxy- $N$-alkoxycarbamates, ${ }^{5} \quad N$-acyloxy- $N$-alkoxyureas, ${ }^{5,6}$ $N, N$-dialkoxyureas, ${ }^{6} N$-alkoxy- $N$-(1-pyridinium)urea salts, ${ }^{6}$ and $N$-chloro- $N$-alkoxyureas ${ }^{7}$ has been established by XRD study of their structure.

In these compounds, the shortening of the N-OAlk bond and the elongation of the $\mathrm{N}-\mathrm{X}$ bond are observed, which we regard as being an $\left.n_{O(A k)}\right)^{-\sigma^{*}} \mathrm{~N}-\mathrm{X}$ orbital interaction, called the anomeric effect. ${ }^{8}$ Most prominently, this phenomenon arises in $N$-alkoxy- $N$-(1-pyridinium)- $N$-tertalkylamines salts. ${ }^{4}$ In the case of $N$-methoxy- $N$-(pyridinium)- $N$-tert-alkylamine salt, ${ }^{4}$ it was observed that the $\mathrm{N}$-OMe bond shortened up to $1.41 \AA^{6}{ }^{6}$ compared with $1.50 \AA$ in $\mathrm{MeNH}-\mathrm{OMe}^{9}$ and up to $1.46 \AA$ for the $\mathrm{N}-\mathrm{O}$ bond in $O$-ethyl- $N$-9-triptycylhydroxylamine. ${ }^{10}$ Also in this salt, ${ }^{4}$ elongation of the $\mathrm{N}-\mathrm{N}^{+}$bond to $1.47 \AA$ was found when compared with $1.45 \AA$ for $\mathrm{N}-\mathrm{N}$ bond length in hydrazine. ${ }^{11}$ The $\mathrm{N}-\mathrm{N}^{+}$bond length is similar to $\mathrm{N}-\mathrm{N}$ bond length, which is observed in $\mathrm{NF}_{2}-\mathrm{NF}_{2}\left(1.49 \AA^{12}\right)$ and $(\mathrm{MeO})_{2} \mathrm{~N}-\mathrm{N}(\mathrm{OMe})_{2}\left(1.48 \AA^{13}\right)$ where this elongation (C) 2008 Wiley-Liss, Inc. is caused by $n_{F}-\sigma^{\star} N-N$ and $n_{O(M e)}-\sigma_{N-N}^{*}$ anomeric interactions, ${ }^{13}$ respectively.

This $\mathrm{N}-\mathrm{N}^{+}$bond destabilization by the $\mathrm{n}_{O^{-}} \sigma^{\star} \mathrm{N}-\mathrm{N}+$ interaction causes possibility of nucleophilic substitution of pyridinium group in $N$-methoxy- $N$-(pyridinium)- $N$-tertalkylamine salts ${ }^{4}$ and $N$-alkoxy- $N$-(pyridinium)- $N^{\prime}, N^{\prime}$-dimethylurea salt. ${ }^{6}$

The high electronegativity of $\mathrm{O}$ - and $\mathrm{X}$-ligands supports the pyramidal configuration of the nitrogen in $\mathrm{O}-\mathrm{N}-\mathrm{X}$ geminal systems. ${ }^{8}$ However, it is possible that the degree of 1-N nitrogen pyramidality may depend of the nature of the $N$-alkoxy group. Because of this phenomenon, it is difficult to carry out the correct analysis of the X-substituent effect on the $\mathrm{N}$-OAlk bond length for $N$-acyloxy- $N$-alkoxyurea with different kinds of $N$-alkoxy groups. The correct analysis only becomes possible for the series of $N$ alkoxy- $N$-X-ureas having the same $N$-alkoxy group. But for

Contract grant sponsor: Russian Foundation for Basic Research; Contract grant number: 06-030-32840.

Contract grant sponsor: Russian Academy of Sciences.

* Correspondence to: Remir G. Kostyanovsky, N.N. Semenov Institute of Chemical Physics, Russian Academy of Sciences, Moscow 119991. Russian Federation. E-mail: kost@icenter.chph.ras.ru

Received for publication 22 May 2008; Accepted 8 September 2008

DOI: $10.1002 /$ chir.20668

Published online 31 October 2008 in Wiley InterSience

(www.interscience.wiley.com)

\section{the \\ tox \\ $\mathrm{ob}$ \\ ${ }^{1} \mathrm{H}$ \\ (1)

$$
\mathrm{Ca}
$$$$
\text { of }
$$$$
\text { Th }
$$ \\ $2 \mathrm{C}$


the series of simplest $N$-methoxy- $N$-X-ureas $(\mathrm{X}=\mathrm{OAc}$ (1), $\mathrm{Cl}$ (2), OMe (3), $\mathrm{N}^{+} \mathrm{C}_{5} \mathrm{H}_{5}$ (4)) only the structure of $\mathrm{N}$-acetoxy- $N$-methoxyurea $\mathbf{1}^{7}$ remains unstudied at this time.

\section{EXPERIMENTAL}

$\mathrm{N}, \mathrm{N}$-bis(methoxycarbonyl)-N-methoxyimide. (5) was obtained as colorless crystals from methyl $N, N$-dimethoxycarbamate $^{14}$ by storing for 6 mo at $15^{\circ} \mathrm{C}$, m.p. $52-54^{\circ} \mathrm{C}$.

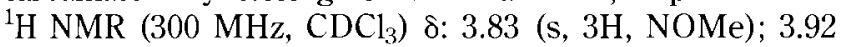
$\left(\mathrm{s}, 6 \mathrm{H}, \mathrm{CO}_{2} \mathrm{Me}\right)$. MS (FAB, $\left.m / z, I_{\text {rel }}(\%)\right): 164[\mathrm{M}+\mathrm{H}]^{+}$ (100); 149 (21.8). Found (\%): C, 36.73; H, 5.77; N, 8.49. Calc. for $\mathrm{C}_{5} \mathrm{H}_{9} \mathrm{NO}_{5}(5)$ : C, 36.81; H, 5.56; N, 8.59.

N-Chloro-N-ethoxyurea (7). A mixture of solution of $t \mathrm{BuOCl}(0.89 \mathrm{~g}, 8.24 \mathrm{mmol})$ in $\mathrm{CH}_{2} \mathrm{Cl}_{2}(10 \mathrm{ml})$ and $\mathrm{N}$-ethoxyurea $(0.57 \mathrm{~g}, 5.49 \mathrm{mmol})$ was kept at $20^{\circ} \mathrm{C}$ for $1 \mathrm{~h}$. The solution was evaporated in vacuo and was kept at $20 \mathrm{C}$ and 2 Torr for $0.5 \mathrm{~h}$, yielding $0.76 \mathrm{~g}(100 \%) \mathrm{N}$-chloro$\mathrm{N}$-ethoxyurea 7 as a white solid, m.p. $53-54 \mathrm{C}$ (with decomp.), after crystallization colorless crystals, m.p. 54$55^{\circ} \mathrm{C}$ (with decomp.) $\left(\mathrm{CH}_{2} \mathrm{Cl}_{2}-\mathrm{C}_{6} \mathrm{H}_{14}\right) .{ }^{1} \mathrm{H}$ NMR $(300$ $\mathrm{MHz}, \mathrm{CDCl}_{3}$ ): 1.26 (t, $\left.3 \mathrm{H}, \mathrm{OCH}_{2} \mathrm{Me}, J=7.2\right) ; 4.04$ (q, $2 \mathrm{H}$, $\left.\mathrm{OCH}_{2} \mathrm{Me}, J=7.2\right) ; 6.09$ (br.s, $\left.2 \mathrm{H}, \mathrm{NH}_{2}\right)$. IR $\left(\mathrm{v} / \mathrm{cm}^{-1}\right)$ : $1725 \quad(\mathrm{C}=\mathrm{O}) . \quad \mathrm{MS} \quad\left(\mathrm{FAB}, \quad \mathrm{H}^{+}, \quad m / z, \quad I_{\mathrm{rel}} \quad(\%)\right): 141$ $[\mathrm{M}+\mathrm{H}]^{+}(32) ; 139[\mathrm{M}+\mathrm{H}]^{+}(100)$. Found (\%): $\mathrm{Cl}, 25.20$. Calc. for $\mathrm{C}_{3} \mathrm{H}_{7} \mathrm{ClN}_{2} \mathrm{O}_{2}$ (\%): $\mathrm{Cl}, 25.59$.

N-4-Chlorobenzoyloxy-N-ethoxyurea (8). $\quad 4-\mathrm{ClC}_{6} \mathrm{H}_{4} \mathrm{CO}_{2}$ $\mathrm{Na}(6.27 \mathrm{mmol}, 6.27 \mathrm{~g})$ and a solution of $N$-chloro- $N$-ethoxyurea $8(3.12 \mathrm{mmol}, 0.43 \mathrm{~g})$ in $\mathrm{MeCN}(20 \mathrm{ml})$ were stirred at $20^{\circ} \mathrm{C}$ for $43 \mathrm{~h}$, then $\mathrm{CH}_{2} \mathrm{Cl}_{2}(10 \mathrm{ml})$ was added. The solid was filtered off, the filtrate was evaporated to $50 \%$ in vacuo, the precipitate was filtered off, and the filtrate was further evaporated in vacuo. The residue was extracted by $\mathrm{CH}_{2} \mathrm{Cl}_{2}$ $(18 \mathrm{ml})$, the extract was evaporated in vacuo, yielding 0.19 g (23.5\%) $N$-4-chlorobenzoyloxy- $N$-ethoxyurea 8 as color-

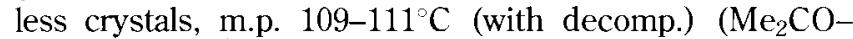
$\left.\mathrm{Et}_{2} \mathrm{O}-\mathrm{C}_{6} \mathrm{H}_{14}\right) .{ }^{1} \mathrm{H}$ NMR $\left(300 \mathrm{MHz}, \mathrm{CDCl}_{3}\right): 1.29(\mathrm{t}, 3 \mathrm{H}$, $\left.\mathrm{OCH}_{2} \mathrm{Me}, J=7.2\right) ; 4.17$ (q, $\left.2 \mathrm{H}, \mathrm{OCH}_{2} \mathrm{Me}, J=7.2\right) ; 5.96$ (br.s, $\left.2 \mathrm{H}, \mathrm{NH}_{2}\right) ; 7.42\left(\mathrm{~d}, 2 \mathrm{H}, \mathrm{C}_{6} \mathrm{H}_{4}, J=9\right) ; 7.96(\mathrm{~d}, 2 \mathrm{H}$, $\left.\mathrm{C}_{6} \mathrm{H}_{4}, J=9\right)$. IR $\left(v / \mathrm{cm}^{-1}\right): 3470(\mathrm{NH}), 1760(\mathrm{C}=\mathrm{O})$. MS $\left(\mathrm{FAB}, \quad \mathrm{Na}^{+}, \quad m / z, \quad I_{\text {rel }}(\%)\right): 283 \quad[\mathrm{M}+\mathrm{Na}]^{+}(23) ; 281$ $[\mathrm{M}+\mathrm{Na}]^{+}(100)$. Found (\%): C, 46.18; H, 4.01; N, 10.94 . Calc. for $\mathrm{C}_{10} \mathrm{H}_{11} \mathrm{ClN}_{2} \mathrm{O}_{4}$. (\%): C, 46.44; $\mathrm{H}, 4.29 ; \mathrm{N}, 10.83$.

X-ray diffraction study of compounds $\mathbf{1}, \mathbf{5}, \mathbf{7}$, and $\mathbf{8}$ was performed at Xcalibur 3 diffractometer (graphite-monochromated $\mathrm{MoK}_{\alpha} \mathrm{CCD}$ detector, (w-scans). Structures were solved by direct methods and refined by full-matrix least squares procedure in anisotropic approximation for nonhydrogen atoms using SHELX-97 program package. ${ }^{15}$ Hydrogen atoms of methylene and methyl groups were placed in calculated positions and included into refinement within riding model with $U_{\mathrm{iso}}(\mathrm{H})=\mathrm{n}_{\mathrm{n}} U_{\mathrm{eq}}(\mathrm{C})(n=1.2$ for $\mathrm{CH}_{2}$ groups and $n=1.5$ for $\mathrm{CH}_{3}$ groups). Hydrogen atoms of amino group were refined isotropically independently. During refinement of the structures 7ALT and 7ART, the $\mathrm{O}(2)-\mathrm{C}(2), \mathrm{C}(2)-\mathrm{C}(3)$ and $\mathrm{O}(1)-\mathrm{C}(1)$ bonds were restrained to have the same bond length in two conformers, with standard deviation of $0.02 \AA$. Crystal data are

summarized in the Table 3 . Full set of atomic coordinates, bond lengths, and bond angles have been deposited at the Cambridge Crystallographic Data Centre (CCDC). These data can be obtained free of charge via www.ccds.cam.uk/ conts/retrievjng.html or deposit@ccdc.cam.ac.uk.

\section{RESULTS AND DISCUSSION}

Therefore, we have studied the crystal structure of 1 by means of XRD ${ }^{\dagger}$.

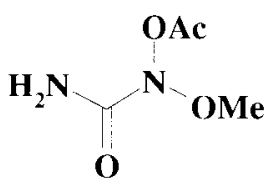

1

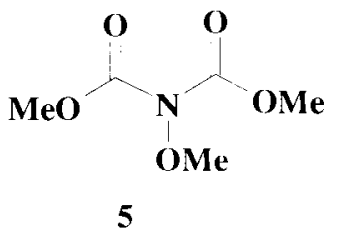

The X-ray diffraction study of $N$-acetoxy- $N$-methoxyurea 1 (see Fig. 1) revealed that amide $\mathrm{O}-\mathrm{N}(1)-\mathrm{O}$-nitrogen $N(1)$ has a pyramidal configuration (the sum of bond angles centered on this atom $(\Sigma \beta)$ is $332.1(1)^{\prime}$, the deviation from the plane of bonded atoms $\left(h_{\mathrm{N}}\right)$ is $\left.0.446(2) \AA\right)$. The orientation of substitutents around the lone pair of $\mathrm{N}(1)$ is almost identical to that observed in $N$-acetoxy- $N$ ethoxyurea. ${ }^{5}$ The $\mathrm{O}-\mathrm{Me}$ and $\mathrm{O}-\mathrm{C}(-\mathrm{O})$ bonds have $-s p$ and -ap-orientations with respect to lone pair (Lp) of $\mathrm{N}(1)$ atom (the $\mathrm{C}(1)-\mathrm{O}(1)-\mathrm{N}(1)-\mathrm{Lp}(\mathrm{N} 1)$ and $\mathrm{C}(3)-\mathrm{O}(4)-\mathrm{N}(1)-\mathrm{Lp}(\mathrm{N} 1)$ torsion angles are 175.4 and $13.8^{\circ}$, respectively). Pyramidality of the $\mathrm{N}(1)$ atom in molecule 1 is higher when compared with $N$-acetoxy- $N$-ethoxyurea $^{5}\left(\Sigma \beta=333.6(2)^{\circ}\right.$ and $\left.h_{N}=0.431(2) \AA\right)$. This results in weaker conjugation between $\mathrm{LpN}(1)$ and carbonyl $\mathrm{C}(=\mathrm{O})-\mathrm{NH}$ fragment, as evidenced from the longer $\mathrm{N}-\mathrm{C}(=\mathrm{O})$ bond in $1(1.446(2) \AA)$ compared with $N$. acetoxy- $N$-ethoxyurea ${ }^{5}$ (1.426(3) $\AA$ ), and also from shorter $\mathrm{H}_{2} \mathrm{~N}-\mathrm{C}(\mathrm{O})$ bond (1.316(2) $\AA$ compared with $\left.1.330(3) \AA\right)$. At the same time, the $\mathrm{N}-\mathrm{OAlk}$ and $\mathrm{N}-\mathrm{OAc}$ bonds have somewhat greater length in urea 1 when compared with $N$-acetoxy- $N$-ethoxyurea ${ }^{5}$ (1.401(2) $\AA$ and $1.434(2) \AA$ in urea $1 ; 1.398(2) \AA$ and $1.426(3) \AA$ in $N$-acetoxy- $N$-ethoxyurea, ${ }^{5}$ respectively). In urea 1 the $N(2)$ atom has planar configuration $\left(\left(\Sigma \beta_{\mathrm{N} 2}=359.9^{\circ}\right)\right.$.

The molecules of $\mathbf{1}$ form centrosymmetrical dimers in the crystal because of the $\mathrm{N}(2)-\mathrm{H}(2 \mathrm{NA}) \cdots \mathrm{O}(4)$ hydrogen bonds $\left(\mathrm{H} \cdots \mathrm{O} 2.05 \AA, \mathrm{N}-\mathrm{H} \cdots \mathrm{O} 171^{\circ}\right.$ ).

In $N$-methoxy- $N$-X-ureas 1-4, the highest degree of pyramidality is observed in ureas 1 and 2 . It was demonstrated that in these ureas X-group is readily substituted by nucleophiles. ${ }^{5-7}$ In salt 4 the nitrogen pyramidality degree is lower. In all cases, the $\mathrm{N}(1)-\mathrm{C}(=0)$ bond is longer than the $\mathrm{N}(2)-\mathrm{C}(=\mathrm{O})$ bond. This difference in bond lengths arises, first, from preferable conjugation of the carbonyl group with the planar nitrogen atom $\mathrm{N}(2)$ than with the pyramidal nitrogen atom $\mathrm{N}(1)$, second, from the difference between $\mathrm{C}-\mathrm{N}\left(s p^{3}\right)$ and $\mathrm{C}-\mathrm{N}\left(s p^{2}\right)$ bonds.

${ }^{\dagger}$ Asymmetric nitrogen, Part 104. For Part 103 see ref. 16. 


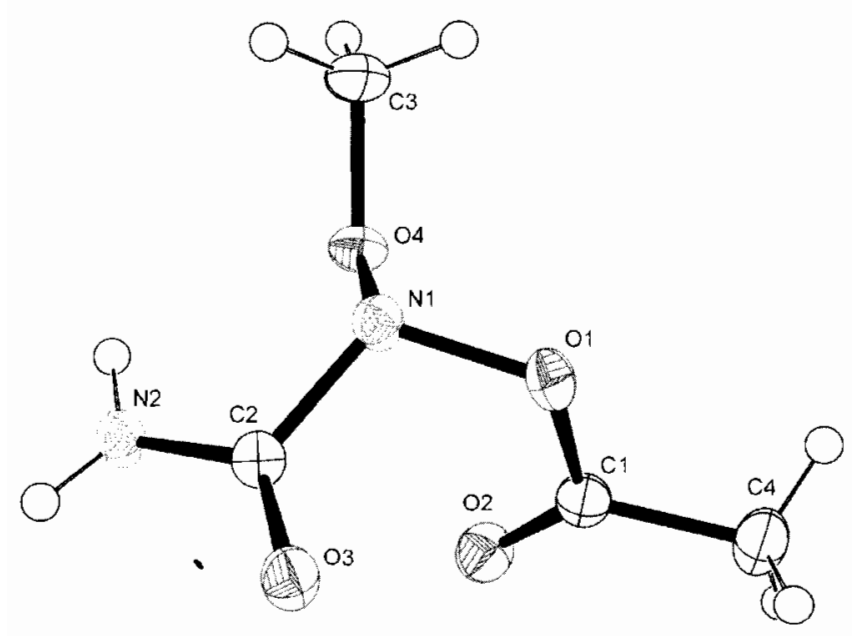

Fig. 1. Molecular structure of 1 . Selected bond lengths ( $(\AA)$ and bond angles ( ): $\mathrm{O}(1)-\mathrm{N}(1) \quad 1.434(2), \quad \mathrm{O}(4)-\mathrm{N}(1)$ 1.401(2), $\mathrm{O}(1)-\mathrm{C}(1)$ $1.385(2), \mathrm{O}(2)-\mathrm{C}(1) 1.194(2), \mathrm{O}(3)-\mathrm{C}(2) 1.232(2), \mathrm{O}(4)-\mathrm{C}(3) 1.443(2)$, $\mathrm{N}(1)-\mathrm{C}(2) \quad 1.445(2), \quad \mathrm{N}(2)-\mathrm{C}(2) \quad 1.317(2), \mathrm{C}(1)-\mathrm{C}(4) \quad 1.494(2)$ $\mathrm{O}(4)-\mathrm{N}(1)-\mathrm{O}(1) \quad 108.68(10), \quad \mathrm{O}(4)-\mathrm{N}(1)-\mathrm{C}(2) \quad 111.70(11)$, $O(1)-\mathrm{N}(1)-\mathrm{C}(2) \quad 111.75(11), \quad \mathrm{C}(1)-\mathrm{O}(1)-\mathrm{N}(1) \quad 114.5(1)$, $\mathrm{N}(1)-\mathrm{O}(4)-\mathrm{C}(3) 114.5(1), \mathrm{O}(2)-\mathrm{C}(1)-\mathrm{O}(1) 123.3(1), \mathrm{O}(2)-\mathrm{C}(1)-\mathrm{C}(4)$ $127.4(2), \quad \mathrm{O}(1)-\mathrm{C}(1)-\mathrm{C}(4) \quad 109.3(1), \quad \mathrm{O}(3)-\mathrm{C}(2)-\mathrm{N}(2) \quad 126.4(2)$, $\mathrm{O}(3)-\mathrm{C}(2)-\mathrm{N}(1) 118.0(1), \mathrm{N}(2)-\mathrm{C}(2)-\mathrm{N}(1) 115.1(1)$. [Color figure can be viewed in the online issue, which is available at www.interscience. wiley.com.]

For these ureas, the lengths of the $\mathrm{N}-\mathrm{O}(\mathrm{Me})$ bond are similar. It may be supposed that this could be caused only by the similar degree of pyramidality of the $\mathrm{N}(1)$ atom. To check this suggestion, we have studied the structure of $N, N$-bis (methoxycarbonyl)- $N$-methoxyimide $5^{\star}$ by means of X-ray diffraction (Fig. 2). This compound was found to be a product of the methyl $N, N$-dimethoxycarbamate ${ }^{14}$ decomposition after the long storage. We believed that in imide 5 the nitrogen must have a planar configuration causing some shortening of $\mathrm{N}-\mathrm{OMe}$ bond length relative to $\mathrm{N}-\mathrm{OMe}$ bond lengths in ureas 1-4.

In imide $\mathbf{5}$ the nitrogen configuration is almost planar ( $\Sigma \beta$ is $359.7(1)^{\circ}$ and $h_{\mathrm{N}}$ is $0.031(1) \AA$ ) in contrast to that in ureas 1-4. Both $\mathrm{MeOC}(\mathrm{O})$-groups and $\mathrm{N}(1)$ atom lie near the same (plane within $0.05 \AA$ ). The $\mathrm{C}(1)-\mathrm{O}(1)$ bond adopts an orthogonal orientation with respect to this plane (the $\mathrm{C}(1)-\mathrm{O}(1)-\mathrm{N}(1)-\mathrm{C}(4)$ torsion angle is $89.3(1)^{\circ}$ ). The planar configuration of $\mathrm{N}(1)$ atom causes the considerable shortening of the $\mathrm{N}-\mathrm{C}$ bonds $(1.397(2)$ and $1.396(2) \AA)$ compared with the $\mathrm{N}-\mathrm{C}$ bonds in anomeric ureas 1-4 (1.44-1.45 $\AA$, see Table 1). At the same time, the length of the $\mathrm{N}-\mathrm{O}$ (Me) bond (1.396(2) $\AA$ ) of planar nitrogen N(1) in molecule 5 is close to those found in the molecules 1-4 containing highly pyramidal nitrogen atoms. This fact reveals the additional shortening of $\mathrm{N}-\mathrm{O}(\mathrm{Me})$ bond lengths of pyramidal $1-\mathrm{N}$ nitrogen in $\mathrm{H}_{2} \mathrm{NC}(\mathrm{O}) \mathrm{N}(\mathrm{X}) \mathrm{OMe}$ ureas 1-4. Undoubtly, the length of planar atom $\left(s p^{2}\right) \mathrm{N}-\mathrm{O}(\mathrm{Me})$ bond cannot be similar to the length of pyramidal atom $\left(s p^{3}\right) \mathrm{N}-\mathrm{O}(\mathrm{Me})$ bond without additional shortening. It could be supposed that this phenomenon results from the action of $n_{O(M e)}{ }^{-}{ }^{*}{ }_{N-X}$ anomeric interaction. ${ }^{9}$ The transfer of lone pair electron density from the oxygen atom of the MeO-group into the $\sigma^{*} \mathrm{~N}-\mathrm{X}$ Chirality DOI $10.1002 /$ chir orbital cause this revealed additional shortening of $\mathrm{N}-\mathrm{O}(\mathrm{Me})$ bond as well as the elongation of $\mathrm{N}-\mathrm{X}$ bond $^{5-7}$ in molecules of family of anomeric ureas 1-4.

For the case of the $N$-chloro- $N$-alkoxyureas, it was also demonstrated that the degree of the nitrogen pyramidality also depends of the nature of the $N$-alkoxy group. ${ }^{7}$ In $N$ chloro- $N$-methoxyurea $2, \Sigma \beta=329.0$ and $h_{\mathrm{N}}=0.500 \AA^{7}$ In $N$-chloro- $N$-alkoxyurea 6 possessing a bulky $N$-alkoxy group, the degree of nitrogen pyramidality is somewhat greater $\left(\Sigma \beta=325.8^{\circ}\right.$ and $\left.h_{\mathrm{N}}=0.533 \AA^{7}\right)$.<smiles>CNC(=O)OC</smiles>

2<smiles>[Y4]C(C)(ON(Cl)C(=O)Nc1ccc([N+](=O)[O-])cc1)C(C)=O</smiles>

6<smiles>CON(Cl)C(N)=O</smiles>

7
To continue the investigation of the influence of the $N$ alkoxy group type on the degree of nitrogen pyramidality, we studied the structure of $N$-chloro- $N$-ethoxyurea $7^{16}$ using XRD. The crystals of 7 were grown from $\mathrm{CH}_{2} \mathrm{Cl}_{2-}$ hexane mixture at $-20^{\circ} \mathrm{C}$, and the XRD study was carried out at 100 (structure $\mathbf{7 L T}$ ) and $250 \mathrm{~K}$ (structure $\mathbf{7 R T}$ ). It was found that in the crystal urea 7 exists as a mixture of two conformers (7A and $\mathbf{7 B}$ ) with population $\mathrm{A}: \mathrm{B}=$ $89: 11 \%$ in structure $\mathbf{7 L T}$ and $84: 16 \%$ in structure $\mathbf{7 R T}$. These two conformers of $\mathbf{7}$ differ in the configuration of the $\mathrm{N}(1)$ atom (Fig. 3, Table 2). In conformation $\mathbf{7 A}$ the $\mathrm{N}(1)$ atom is strongly pyramidal $\left(h_{\mathrm{N}}=0.499 \AA\right.$ and $\Sigma \beta=$ $328.93(8)^{\circ}$ in 7LT and $h_{\mathrm{N}}=0.491 \AA, \Sigma \beta=329.7(1)$ in 7KT) similar to $N$-chloro- $N$-alkoxyureas 2 and 6 . In conformation $\mathbf{7 B}$ this nitrogen atom adopts significantly flattened configuration $\left(h_{N}=0.264 \AA\right.$ and $\Sigma \beta=350.5(4)$ in 7LT and $h_{\mathrm{N}}=0.256 \AA, \Sigma \beta=350.7(5)$ in $\mathbf{7 R T}$ ) similar to

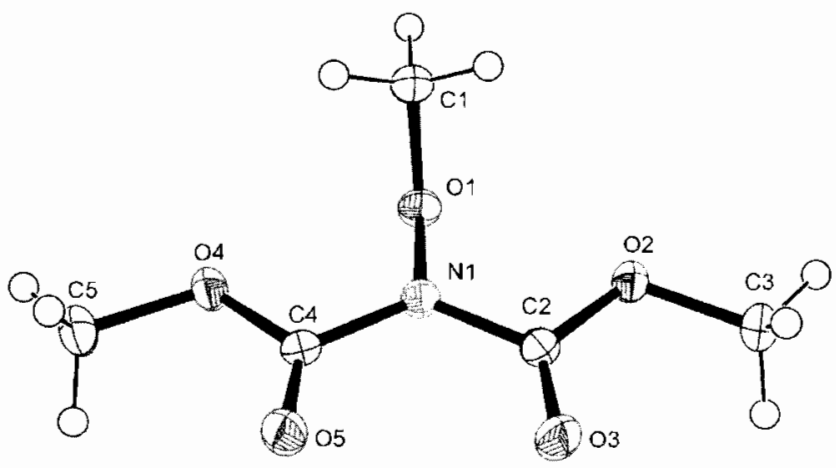

Fig. 2. Molecular structure of $\mathbf{5}$. Selected bond lengths $(\AA)$ and bond angles ()$: \quad \mathrm{O}(1)-\mathrm{N}(1) \quad 1.396(1), \quad \mathrm{O}(1)-\mathrm{C}(1) \quad 1.448(2), \quad \mathrm{O}(2)-\mathrm{C}(2)$ 1.338(2), O(2)-C(3) 1.450(2), O(3)-C(2) 1.197(2), O(4)-C(4) $1.338(2)$, $\mathrm{O}(4)-\mathrm{C}(5) \quad 1.449(2), \quad \mathrm{O}(5)-\mathrm{C}(4) \quad 1.200(2), \quad \mathrm{N}(1) \mathrm{C}(4) \quad 1.396(2)$, $\mathrm{N}(1)-\mathrm{C}(2) \quad 1.397(2) ; \quad \mathrm{O}(1)-\mathrm{N}(1)-\mathrm{C}(4) \quad 118.2(1), \quad O(1)-\mathrm{N}(1)-\mathrm{C}(2)$ $117.8(1), \quad \mathrm{C}(4)-\mathrm{N}(1)-\mathrm{C}(2) \quad 123.8(1), \quad \mathrm{N}(1)-\mathrm{O}(1) \quad \mathrm{C}(1) \quad 109.8(1)$, $\mathrm{C}(2)-\mathrm{O}(2)-\mathrm{C}(3) 114.2(1), \mathrm{C}(4)-\mathrm{O}(4)-\mathrm{C}(5) 115.0(1), \mathrm{O}(3)-\mathrm{C}(2) \cdot \mathrm{O}(2)$ $125.5(1), \quad \mathrm{O}(3)-\mathrm{C}(2)-\mathrm{N}(1) \quad 124.7(1), \quad \mathrm{O}(2)-\mathrm{C}(2)-\mathrm{N}(1) \quad 109.9(1)$, $\mathrm{O}(5)-\mathrm{C}(4)-\mathrm{O}(4) 126.0(1), \mathrm{O}(5)-\mathrm{C}(4)-\mathrm{N}(1) 124.6(1), 0(4) \cdot \mathrm{C}(4) \cdots \mathrm{N}(1)$ 109.4(1). [Color figure can be viewed in the online issue, which is available at www.interscience.wiley.com.] 
TABLE 1. Some structural parameters of $\mathrm{H}_{2} \mathrm{NC}(\mathrm{O}) \mathrm{N}(\mathrm{X}) \mathrm{OMe}$ ureas $1-4$ and $\left(\mathrm{MeO}_{2} \mathrm{C}\right)_{2} \mathrm{NOMe} 5$

\begin{tabular}{|c|c|c|c|c|c|}
\hline \multirow[b]{2}{*}{ Parameter } & \multicolumn{4}{|c|}{$\mathrm{X}$} & \multirow[b]{2}{*}{ For $(\mathrm{MeO}, \mathrm{C})_{2} \mathrm{NOMe} 5$} \\
\hline & OAc, 1 & $\mathrm{Cl}, 2^{7}$ & OMe, $3^{6}$ & $\mathrm{~N}^{+} \mathrm{C}_{5} \mathrm{H}_{5}, 4^{\mathrm{ij}}$ & \\
\hline$\Sigma \beta_{\mathrm{N} 1}()$ & $332.1(1)$ & $329.0(2)$ & $331.8(2)$ & $333.9(1)$ & $359.7(1)$ \\
\hline$h_{\mathrm{N} 1}(\AA)$ & $0.446(2)$ & $0.500(1)$ & $0.444(2)$ & $0.431(2)$ & $0.031(1)$ \\
\hline $\mathrm{N}$-OMe length $(\AA)$ & $1.401(2)$ & $1.398(1)$ & $1.398(3), 1.399(2)$ & $1.400(2)$ & $1.396(1)$ \\
\hline $\mathrm{N}(1)-\mathrm{C}(=\mathrm{O})$ length $(\AA)$ & $1.445(2)$ & $1.443(2)$ & $1.438(2)$ & $1.452(2)$ & \\
\hline $\mathrm{N}(2)-\mathrm{C}(=\mathrm{O})$ length $(\AA)$ & $1.317(2)$ & $1.320(2)$ & $1.320(3)$ & $1.323(2)$ & $1.397(2), 1.396(2)$ \\
\hline
\end{tabular}

that in common ureas. The difference in configuration of the $N(1)$ atom reşults in disordering of the ethoxy group, chlorine atom, and oxygen atom of carbonyl group.<smiles>CCONC(N)=O</smiles>

$7 \mathbf{A}$<smiles>CCON(Cl)C(N)=O</smiles>

7B
Flattened configuration of the $\mathrm{N}(1)$ atom in conformation $7 \mathrm{~B}$ causes significant shortening of the $\mathrm{N}-\mathrm{Cl}$ bond (by $0.09 \AA$ in 7LT and $0.15 \AA$ in 7RT) and the $\mathrm{N}-\mathrm{O}$ bond (by $0.07 \AA$ in $7 \mathbf{L T}$ and $0.06 \AA$ in $\mathbf{7 R T}$ ). This results from drastic change of intramolecular interactions within molecule 7 because of change of N(1) atom configuration. Orientation of the ethoxy group with respect to lone pair of the nitrogen atom in conformers $\mathbf{7 A}$ and $\mathbf{7 B}$ indicates that the $\mathrm{Lp}(\mathrm{N} 1) \rightarrow \sigma^{\star}(\mathrm{C} 2-\mathrm{C} 3)$ orbital interaction is possible only in conformer $7 \mathrm{~A}$. The $\mathrm{N}(1)-\mathrm{O}(2)-\mathrm{C}(2)-\mathrm{C}(3)$ torsion angle in conformer $\mathbf{7 A}$ is $-177.8(1)^{\circ}$ in $7 \mathrm{LT}$ and $-179.7(3)$ in $\mathbf{7 R T}$. In conformation $\mathbf{7 B}$ this angle is $83(2)$ (7LT) and $89(2)$ (7RT). But this orbital interaction cannot strictly regards as an anomeric interaction. It should be noted that the change of pyramidality degree of the $N(1)$ atom does not influence on the length of $N(1)-C(1)$ bond. Detailed inspection of the thermal ellip-

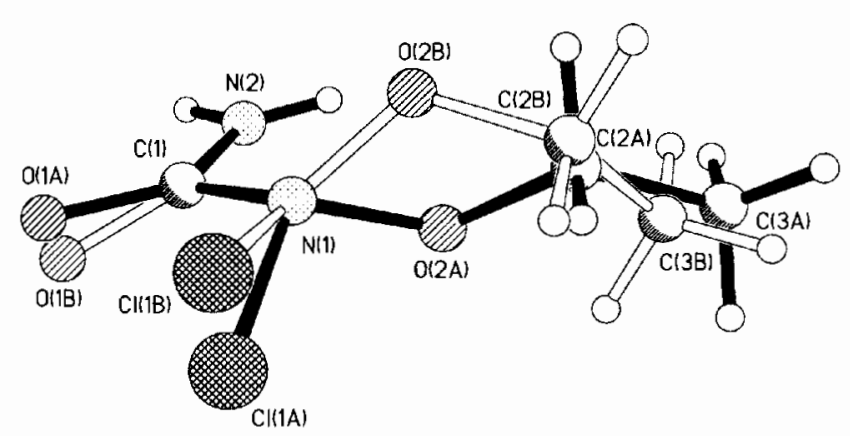

Fig. 3. The structure of conformations $\mathbf{7 A}$ (black) and $\mathbf{7 B}$ (white) in $N$-chloro- $N$-ethoxyurea. soid of the $\mathrm{C}(1)$ atom does not indicate any even a small potential disorder.

Despite of difference in structure of two conformers of molecule 7 , both of them have similar crystal packing and character of intermolecular interactions in the solid state. In the crystal molecules of $\mathbf{7}$ exist as centrosymmetric dimers because of intermolecular hydrogen bonds $\mathrm{N}(2)-\mathrm{H}(2 \mathrm{NB}) \cdots \mathrm{O}(1)^{\prime} \quad(1-\mathrm{x}, 1-\mathrm{y}, 1-\mathrm{z}) \quad(\mathrm{H} \cdots \mathrm{O} \quad 2.07 \quad \AA$, $\mathrm{N}-\mathrm{H} \ldots \mathrm{O} 174 \quad(7 \mathrm{~A}, \mathbf{L T}), 2.10 \AA, 171 \quad$ (7B, LT), $2.04 \AA$, 172 (7A, RT), $2.06 \AA$, 174 (7B, RT). These dimers form infinite chains along crystallographic direction $\left(\begin{array}{lll}0 & 0 & 1\end{array}\right)$ because of weak intermolecular hydrogen bonds $\mathrm{N}(2)-\mathrm{H}(2 \mathrm{NA}) \cdots \mathrm{O}(1) \quad(\mathrm{x}, 0.5-\mathrm{y},-0.5+\mathrm{z}) \quad(\mathrm{H} \cdots \mathrm{O} 2.28 \quad \AA$, $\mathrm{N}-\mathrm{H} \cdots \mathrm{O} 154$ (7A, LT), $2.34 \AA$, 164 (7B, LT), $2.33 \AA$, 156 (7A, RT), $2.41 \AA, 165$ (7B, RT).

Similar amounts of relative populations of both conformation of molecule 7 at 100 and $250 \mathrm{~K}$ and also the absence of strong short intermolecular contacts between disordered atoms of conformations A and B prevent conclusions about the nature of this disordering in the crystal of 7. For example, both statistic disordering with the absence of transfer between conformations $\mathbf{A}$ and $\mathbf{B}$ and dynamic disordering having the negligible temperature dependence of free energies are possible.

As well as in $N$-chloro- $N$-alkoxyureas and $N$-acyloxy- $N$ alkoxyureas, the type of $\mathrm{N}$-acyloxy substituent and $\mathrm{N}$ alkoxy substituent have a significant influence on nitrogen pyramidality degree and overall conformation of molecule. The XRD study of $N$-4-chlorobenzoyloxy- $N$-ethoxyurea 8 (see Fig. 4) revealed that pyramidality at $\mathrm{N}(1) \quad(\Sigma \beta=$ $329.32(8)$ and $h_{\mathrm{N}}=0.470(1) \AA$ ) is somewhat higher than in $N$-acetoxy- $N$-methoxyurea 1 and in $N$-acetoxy- $N$-ethoxyurea. ${ }^{5}$ But the degree of pyramidality in $\mathbf{8}$ is considerably smaller when compared with $N$-4-chlorobenzoyloxy-

TABLE 2. Selected bond length (Å) and bond angles ( ) in conformations $7 \mathrm{~A}$ and $7 \mathrm{~B}$

\begin{tabular}{lccccc}
\hline & \multicolumn{2}{c}{ 7LT } & & \multicolumn{2}{c}{ 7RT } \\
\cline { 2 - 3 } \cline { 5 - 6 } & $\mathbf{A}$ & $\mathbf{B}$ & & $\mathbf{A}$ & $\mathbf{B}$ \\
\hline $\mathrm{Cl}(1)-\mathrm{N}(1)$ & $1.757(1)$ & $1.670(3)$ & $1.755(2)$ & $1.610(3)$ \\
$\mathrm{O}(2)-\mathrm{N}(1)$ & $1.383(1)$ & $1.318(7)$ & & $1.370(2)$ & $1.307(8)$ \\
$\mathrm{N}(1)-\mathrm{C}(1)$ & \multicolumn{2}{c}{$1.447(1)$} & & \multicolumn{2}{c}{$1.439(2)$} \\
$\mathrm{N}(2)-\mathrm{C}(1)$ & $1.324(1)$ & & \multicolumn{2}{c}{$1.315(2)$} \\
$\mathrm{O}(1)-\mathrm{C}(1)-\mathrm{N}(1)-\mathrm{Cl}(1)$ & $29.8(2)$ & $-20.2(7)$ & & $31.5(3)$ & $-22(1)$ \\
$\mathrm{O}(1)-\mathrm{C}(1)-\mathrm{N}(1)-\mathrm{O}(2)$ & $150.4(1)$ & $-165.6(7)$ & $152.4(2)$ & $-168(1)$ \\
\hline
\end{tabular}




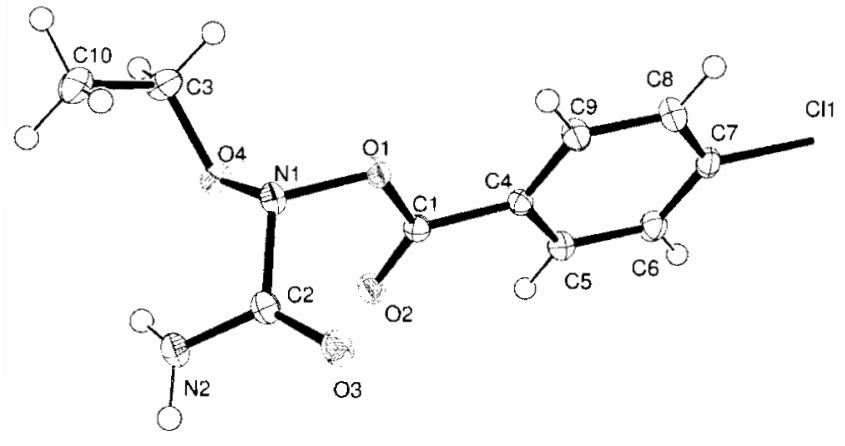

Fig. 4. Molecular structure of 8 . Selected bond lengths $(\AA)$ and bond angles ()$: \quad \mathrm{O}(1)-\mathrm{C}(1) \quad 1.380(1), \quad \mathrm{O}(1)-\mathrm{N}(1) \quad 1.437(1), \quad \mathrm{O}(2)-\mathrm{C}(1)$ $1.204(1), \mathrm{O}(3)-\mathrm{C}(2) 1.223(1), \mathrm{O}(4)-\mathrm{N}(1) 1.4022(1), \mathrm{O}(4)-\mathrm{C}(3) 1.452(1)$, $\mathrm{N}(1)-\mathrm{C}(2) 1.459(1), \mathrm{N}(2)-\mathrm{C}(2) 1.331(1), \mathrm{O}(4)-\mathrm{N}(1)-\mathrm{O}(1) 108.80(7)$, $O(4)-N(1)-C(2) 110.75(8), O(1)-N(1)-C(2)$ 109.77(8). [Color figure can be viewed in the online issue, which is available at www.interscience. wiley.com.]

$N$-(n-butyloxy)urea $\left(\Sigma \beta=323.8^{\circ} \text { and } h_{N}=0.511 \AA\right)^{6}$ and $N$-benzoyloxy- $N$-benzyloxybenzamides $\left(\Sigma \beta=323.51^{\circ}-\right.$ $324.14)^{17}$<smiles>CCOC(=O)ON(OCC)C(N)=O</smiles>

Molecule 8 contains two almost planar fragments: the benzoyloxy group (the $\mathrm{C}(5)-\mathrm{C}(4)-\mathrm{C}(1)-\mathrm{O}(2)$ torsion angle is $\left.4.7(1)^{\circ}\right)$ and the $\mathrm{NH}_{2}-\mathrm{C}(-\mathrm{O})-\mathrm{N}$ moiety. The benzoyloxy group is oriented toward the bisect of the
$\mathrm{C}(2)-\mathrm{N}(1)-\mathrm{O}(4)$ bond angle (the $\mathrm{C}(2)-\mathrm{N}(1)-$ $\mathrm{O}(1)-\mathrm{C}(1)$ and $\mathrm{C}(2)-\mathrm{N}(1)-\mathrm{O}(1)-\mathrm{C}(1)$ torsion angles are $56.6(1)^{\circ}$ and $-64.8(1)$, respectively). In contrast to $N$-4-chlorobenzoyloxy- $N$-( $n$-butyloxyurea $)^{6}$ and $N$-benzoyloxy- $N$-benzyloxy amides ${ }^{17}$ in compound $\mathbf{8}$, this substitutent with the carbonyl group located at endo to the nitrogen pyramid. The ethoxy group is turned with respect to the $\mathrm{NH}_{2-}-\mathrm{C}(-\mathrm{O})$ bond (the $\mathrm{N}(2)-\mathrm{C}(2)-\mathrm{N}(1)-\mathrm{O}(4)$ torsion angle is $\left.-31.7(1)^{\circ}\right)$ and it has - sc conformation (the $\mathrm{N}(1)-\mathrm{O}(4)-\mathrm{C}(3)-\mathrm{C}(10$ torsion angle is $-70.1(1))$.

The anomeric interaction $\mathrm{n}_{O(\mathrm{Et})} \rightarrow \sigma^{*}{ }_{\mathrm{NOC}(\mathrm{O}) \mathrm{Ar}}$ within the $\mathrm{O}-\mathrm{N}-\mathrm{O}$ fragment leads to a significant elongation of the $\mathrm{N}(1)-\mathrm{O}(1) \quad(1.437(1) \AA)$ bond when compared with

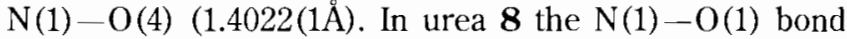
is slightly longer when compared with $N$-acetoxy- $N$-ethoxyurea $^{5}$ and is close to that in $N$-acetoxy- $N$-methoxyurea 1. In $N$-4-chlorobenzoyloxy- $N$-( $n$-butyloxy) urea, ${ }^{6}$ this $\mathrm{N}-\mathrm{OC}(\mathrm{O}) \mathrm{Ar}$ bond is somewhat longer $(1.447(2) \AA)$.

Value of the amide $\mathrm{N}(1)-\mathrm{C}(=\mathrm{O})$ bond $(1.459(1) \AA)$ indicates on a weak conjugation between the lone pair of the $N(1)$ atom and the $\pi$-system of carbonyl group and this bond is even longer than reported for high pyramidal $N$-acyloxy- $N$-alkoxyureas ${ }^{5,6}$ and $N$-acyloxy- $N$-alkoxyamides. ${ }^{17}$ The $\mathrm{N}(2)$ atom has very flattened configuration $\left(\left(\Sigma \beta_{\mathrm{N} 2}=\right.\right.$ $\left.354(2)^{\circ}\right)$. The $\mathrm{N}(2)-\mathrm{C}(=\mathrm{O})$ bond is much shorter $(1.331(1)$ $\AA)$ than $\mathrm{N}(1)-\mathrm{C}(=\mathrm{O})$ bond. In $N$-4-chlorobenzoyloxy- $N$ - $(n-$ butyloxy)urea, ${ }^{6}$ this $\mathrm{N}-\mathrm{C}(=\mathrm{O})$ bond is somewhat shorter (1.321(2) ̊). ${ }^{6}$

In the crystal, molecules of $\mathbf{8}$ exist as centrosymmetric dimers because of intermolecular hydrogen bonds $\mathrm{N}(2)-\mathrm{H}(2 \mathrm{NB}) \cdots \mathrm{O}(3)^{\prime}(-\mathrm{x}, \mathrm{y}, 2-\mathrm{z})(\mathrm{H} \cdots \mathrm{O} 2.07 \AA, \mathrm{N}-\mathrm{H} \cdots \mathrm{O} 168)$.

Replacement of ethoxy group in molecules 8 by butoxy substituent in $N$-4-chlorobenzoyloxy- $N$-( $n$-butyloxy)urea ${ }^{6}$ results in changes of conformation and geometrical parame-

TABLE 3. Crystal data and structure refinement for $1,5,8,7$ ALT and 7ART conformations

\begin{tabular}{|c|c|c|c|c|c|}
\hline & 1 & 5 & 7ALT & 7ART & 8 \\
\hline Temperature (K) & 100 & 100 & 100 & 250 & 100 \\
\hline Crystal system & Monoclinic & Monoclinic & Monoclinic & Monoclinic & Triclinic \\
\hline Space group & $P 2_{1} / c$ & $P 2_{1} / n$ & $P 2_{1} / c$ & $P 2_{1} / c$ & $P \overline{1}$ \\
\hline$a(\AA)$ & $11.1338(8)$ & $7.5027(3)$ & $8.3467(2)$ & $8.5594(6)$ & $7.0438(10)$ \\
\hline$b(\AA)$ & $6.2359(5)$ & $6.9365(3)$ & $7.4406(2)$ & $7.4585(5)$ & $7.4780(9)$ \\
\hline$c(\AA)$ & $10.0614(7)$ & $13.8194(5)$ & $10.2170(3)$ & $10.3026(6)$ & $11.7202(15)$ \\
\hline$\alpha()$ & 90 & 90 & 90 & 90 & $85.569(10)$ \\
\hline$\beta(0)$ & $97.440(6)$ & $98.611(4)$ & $96.999(2)$ & $97.740(5)$ & $84.911(11)$ \\
\hline$\gamma()$ & 90 & 90 & 90 & 90 & $70.315(12)$ \\
\hline$V\left(\AA^{3}\right)$ & $692.67(9)$ & $711.09(5)$ & $629.79(3)$ & $651.73(7)$ & $578.24(13)$ \\
\hline$Z$ & 4 & 4 & 4 & 4 & 2 \\
\hline$d_{\text {calc }}\left(\mathrm{g} \mathrm{cm}^{-1}\right)$ & 1.42 & 1.52 & 1.46 & 1.41 & 1.49 \\
\hline$\mu\left(\mathrm{mm}^{-1}\right)$ & 0.13 & 0.14 & 0.52 & 0.50 & 0.335 \\
\hline$F\left(\begin{array}{lll}0 & 0 & 0\end{array}\right)$ & 312 & 344 & 288 & 288 & 268 \\
\hline $20_{\max }()$ & 60 & 52.8 & 60 & 60 & 60 \\
\hline Reflections collected & 3290 & 2261 & 7806 & 4119 & 11415 \\
\hline Unique reflections & $1945 R_{\mathrm{int}}=0.021$ & $1409 R_{\mathrm{int}}=0.014$ & $1831 R_{\mathrm{int}}=0.025$ & $1870 R_{\mathrm{int}}=0.020$ & $3320 R_{\mathrm{int}}=0.024$ \\
\hline Number of parameters & 101 & 103 & 127 & 127 & 172 \\
\hline$R_{1}[I>2 \sigma(I)]$ & $0.041[1194]$ & $0.036[1151]$ & $0.033[1725]$ & $0.043[1323]$ & $0.033[2973]$ \\
\hline$w R_{2}$ (all data) & 0.102 & 0.102 & 0.079 & 0.119 & 0.086 \\
\hline GOF & 1.00 & 1.06 & 1.04 & 1.08 & 1.07 \\
\hline $\mathrm{CCDC}$ reference number & 679787 & 679788 & 681996 & 681997 & 698694 \\
\hline
\end{tabular}


ters of molecule. In $N$-4-chlorobenzoyloxy- $N$-( $n$-butyloxy) urea, ${ }^{6}$ the benzoyloxy group has an opposite orientation when compared with urea $\mathbf{8}$. Because of rotation around the $\mathrm{N}-\mathrm{O}$ bond, the carbonyl group of this substituent is oriented in the same direction as lone pair of amide nitrogen atom. ${ }^{6}$ Other conformational parameters of molecule remain almost unchanged. In urea $\mathbf{8}$, this change causes a significant decrease of the amide nitrogen pyramidality when compared with $N$-4-chlorobenzoyloxy- $N$ - $(n$-butyloxy)urea. ${ }^{6}$ In latter, the parallel orientation of the lone pair of the amide nitrogen and carbonyl group should lead to considerable repulsion between lone pairs of heteroatoms. This may explain elongation of the $\mathrm{N}-\mathrm{OC}(\mathrm{O}) \mathrm{Ar}$ bond in molecule of $N$-4-chlorobenzoyloxy- $N$-( $n$-butyloxy) urea when compared with urea 8.

\section{CONCLUSIONS}

We can therefore conclude that the degree of pyramidality of amide nitrogen in the compound may be tuned by the orientation of benzoyloxy substituent. However, results of X-ray diffraction study of compounds 8 and $N$-4chlorobenzoyloxy- $N$-( $n$-butyloxy) urea ${ }^{6}$ reveal that orientation of this substituent in turn can be tuned by the size of the $N$-alkoxy group.

\section{LITERATURE CITED}

1. Kostyanovky RG, Rudchenko VF, Shtamburg VG, Chervin II, Nasibov SS. Synthesis, configurational stability, and resolution $N, N$-dialkoxyamines into antipodes. Tetrahedron 1981;37:4245-4254.

2. Rudchenko VF. Reactions, and properties of ONO systems. Chem Rev 1993;93:725-739.

3. Rudchenko VF, Kostyanovsky RG. Geminal systems $\mathrm{O}-\mathrm{N}-\mathrm{Hal}$. Derivatives of $N$-halogenhydroxylamines. Usp Khim 1998;67:203-218.

4. Stamburg VG, Tsygankov AV, Klots EA, Fedyanin IV, Lyssenko KA, Kostyanovsky RG. $N, N$-Dimethoxy- $N$-tert-alkylamines: new synthesis method and the crystal structure of the precursor. Mendeleev Commun 2006;2:84-85.

5. Shishkin OV, Zubatyuk RI, Shtamburg VG, Tsygankov AV, Klots EA, Mazepa AV, Kostyanovsky RG. Pyramidal amide nitrogen in $N$-acy- loxy- $N$-alkoxyureas and $N$-acyloxy- $N$-alkoxycarbanates. Mencleleev Commun 2006;4:222-223.

6. Shtamburg VG, Shishkin OV, Zubatuk RI, Kravchenko SV, Tsygankov AV, Shtamburg VV, Distanov VB, Kostyanovsky RG. Synthesis, structure and properties of $N$-alkoxy- $N$-(1-pyridinium)urea salts, $N$-acyloxy$N$-alkoxyureas and $N, N$-dialkoxyureas. Mendeleev Commun 2007;1: 178-180.

7. Shtamburg VG, Shishkin OV, Zubatuk RI, Kravchenko SV, Tsygankov AV, Mazepa AV, Klots EA, Kostyanovsky RG. $N$-Chloro- $N$-alkoxyureas: synthesis, structure and properties. Mendeleev Commun 2006;6:323-325.

8. Glover SA. Anomeric amides-structure, properties and reactivity. Tetrahedron 1998;54:7229-7271.

9. Rankin DWH, Todd MR, Riddel FG, Turner ES. The molecular structures of $\mathrm{O}$-methylhydroxylamine, $\mathrm{N}$-methylhydroxylamine, $\mathrm{N}, \mathrm{O}$-dimethylhydroxylamine and $N, N, O$-trimethylhydroxylamine in the gas phase, determined by electron diffraction. J Mol Struct 1981;71:171-182.

10. Yamamoto G, Agawa C, Minoura M. Static and dynamic stereochemistry of $O$-substituted $N$-triptycylhydroxylamines. Bull Chem Soc Jpn 2003;76:825-829.

11. Tsuboi M, Overend J. Amino wagging and inversion in hydrazines: ${ }^{k} R$ branch of the antisymmetric wagging band of $\mathrm{NH}_{2} \mathrm{NH}_{2}$. J Mol Spectr 1974;52:256-268.

12. Cardillo MJ, Bauer SH. Structures of gauche- and trans-tetrafluorohydrazine as determined by electron diffraction. Inorg Chem 1969;8: 2086-2092.

13. Antipin MYu, Struchkov YuT, Rudchenko VF, Ignatov SM, Kostyanovsky RG. Geminal systems. 49. Molecular structure of tetramethoxyhydrazine in a crystall. Bull Acad Sci USSR Div Chem Sci (Engl Transl) 1989;38:1672-1675.

14. Shtamburg VG, Klots EA, Pleshkova AP, Avramenko VI, Ivonin SP. Tsygankov AV, Kostyanovsky RG. Synthesis and alkoholysis of $N$-acyloxy-N-alkoxy derivatives of ureas, carbamates, and benzamides. lzv Akad Nauk Ser Khim 2003;10:2132-2140. [Russ Chem Bull Int Ed 2003;52:2251-2260].

15. Sheldrick GM. SHELX97-programs for crystal structure analysis (Release 97-2). Instituit für Anorganische Chemie der Universität, Tammanstrasse 4, D-3400 Göttingen, Germany, 1998.

16. Kostyanovsky RG, Lyssenko KA, Krutius ON, Kostyanovsky VR. The isomorphism of chiral ammonium salts $\mathrm{Ph}$ (All) $\mathrm{N}+\mathrm{Et}(\mathrm{Me}) \mathrm{X} \cdot \mathrm{CHCl}$, $\mathrm{X}=\mathrm{Br}, \mathrm{l}$. Asymmetric Nitrogen. Part 103. Mendeleev Commun 2008; (in press).

17. Gillson A-ME, Glover SA, Tucker DJ, Turner P. Crystal structures and properties of mutagenic $N$-acyloxy- $N$-alkoxyamides-"most pyramidal" acyclic anides. Org Biomol Chem 2003;1:3430-3437. 